\title{
ABSENCE OF RECOVERY IN A DEGRADED EELGRASS (ZOSTERA MARINA) BED IN NOVA SCOTIA, CANADA: RESULTS FROM A TRANSPLANT STUDY
}

\author{
ERIN WILSON AND DAVID J. GARBARY* \\ Jack McLachlan Laboratory of Aquatic Plant Resources, \\ Department of Biology, St. Francis Xavier University, \\ Antigonish, NS B2G 2 W5
}

\begin{abstract}
By the early 2000s, the invasion of the European green crab (Carcinus maenas) had caused a severe decline of eelgrass (Zostera marina) beds in eastern Canada. The formerly lush eelgrass bed in Benoit Cove, Nova Scotia, was extirpated by 2009 and has subsequently failed to recover. The objective of our study was to establish if Benoit Cove (BC) has reached a new equilibrium in which eelgrass cannot recolonize. From July 3 - August 29, 2018, we transplanted eelgrass using frames and monitored eelgrass growth and survival relative to the nearby donor (control) site in Tracadie West Arm (TWA) that had an extensive eelgrass meadow with over $95 \%$ cover. Transplant survival was $91.6 \%$ and $15.4 \%$ for TWA and $\mathrm{BC}$, respectively $(\mathrm{P}<0.001)$. Above-ground growth declined at both sites, and could be associated with high summer water temperatures and/ or extreme epiphytism. Sediments at both sites had high silt composition $(>28 \%$ ), and the absence of a macrophyte canopy lead to increased light attenuation in $\mathrm{BC}$ in moderate wind and tidal currents. The low density of green crabs in both BC and TWA $\left(0.01 \mathrm{~m}^{-2}\right.$ and $0.08 \mathrm{~m}^{-2}$, respectively), and the apparently healthy eelgrass bed in TWA, suggest that green crabs are not having a negative effect on eelgrass in this system and are not responsible for the lack of recolonization of eelgrass in BC.
\end{abstract}

Keywords: Atlantic Canada; eelgrass bed; European green crab; transplant; Zostera marina

\section{INTRODUCTION}

Zostera marina, commonly known as eelgrass, is a vascular marine macrophyte that forms extensive perennial beds in subtidal and intertidal habitats (Green and Short 2003, Vandermeulen et al. 2012). Eelgrass beds occur along all three Canadian ocean coastlines

\footnotetext{
* Author to whom correspondence should be addressed: dgarbary@gmail.com
} 
but are most abundant in Atlantic Canada (Vandermeulen et al. 2012). Eelgrass is the dominant macrophyte in shallow estuaries in the southern Gulf of St. Lawrence of all three Maritime Provinces. In addition to their physical structuring of these environments and their primary production, eelgrass beds provide shelter and support for an abundance of aquatic animal and plant communities as well as waterfowl species (Burkholder and Doheny 1968, Seymour et al. 2002). The combination of a unique rooting system and elongated blades help eelgrass baffle wave energy, prevent coastal erosion, maintain water quality and clarity, facilitate nutrient cycling, and absorb carbon dioxide (Davis and Short 1997, Malyshev and Quijón 2011, Orth and McGlathery 2012, Neckles 2015). In the early 1930s, eelgrass beds in North America experienced a decline of over $90 \%$ which brought attention to its major contribution to marine food webs (Bertness 2007). The extreme die-off of eelgrass was caused by 'wasting disease', an infection of the slime mold pathogen Labyrinthula zosterae (Muehlstein et al. 1991), and it took 30-40 years for these areas to recover (Short and Short 2003).

On a global scale, seagrass cover has declined $7 \%$ each year since the 1990s (Waycott et al. 2009). Over the last two decades, direct and indirect anthropogenic impacts have been responsible for nearly $18 \%$ of the globally reported seagrass decline (Duarte et al. 2004). In eastern North America, current eelgrass decline is often a result of pollution and physical disturbance caused by increased human population along the coast (Short and Burdick 1996).

An indirect anthropogenic impact known to influence the distribution and health of eelgrass beds is the introduction of invasive species. Since the early 2000 s, the invasion by and settlement of the European green crab (Carcinus maenas) has contributed to a severe decline in eelgrass beds in estuarine habitats in Atlantic Canada (Seymour et al. 2002, Malyshev and Quijón 2011, Garbary et al. 2014). From 2001 to 2002, 13 estuaries along the southern Gulf of St. Lawrence had a mean above-ground biomass decline of nearly 40\% (Hanson 2004). In Newfoundland, a Before-After-Control-Impact (BACI) study showed that eelgrass habitats with green crabs experienced a $50 \%$ decline in biomass since 1998 and up to $100 \%$ loss for sites that have had large populations of green crabs for an extended period (Matheson et al. 2016). In Antigonish Harbour, Nova Scotia, eelgrass beds underwent a $95 \%$ loss of biomass in one year, which caused a $50 \%$ 
decline in the number of migrating geese and duck species that depend on those beds (Seymour et al. 2002). The removal of eelgrass shoots is caused by the green crabs' natural behaviour. In soft-sediment habitats, adult and juvenile green crabs dig pits into the substrate for food and shelter which leads to the uprooting of eelgrass shoots (Malyshev and Quijón 2011, Garbary et al. 2014).

\section{RESEARCH PURPOSE AND OBJECTIVES}

Tracadie Harbour (TH), in St. Georges Bay on the north shore of Nova Scotia facing the Gulf of St. Lawrence (Fig. 1), was heavily impacted by the green crab invasion. While nearby habitats such as Antigonish Harbour and Pomquet Harbour have largely recovered over the years, the small inlet of Benoit Cove, appears to have entered a new stable state in which eelgrass has been unable to recover. In 2002, roughly $50,000 \mathrm{~m}^{2}$ of Benoit Cove's (BC) total area $(68,400$ $\mathrm{m}^{2}$ ) comprised a dense bed of Z. marina (Garbary et al. 2014). From July to September 2002 eelgrass density declined from 175 shoots $\mathrm{m}^{-2}$ to less than 50 shoots $\mathrm{m}^{-2}$, and this decline was associated with green crab foraging (Garbary et al. 2014). Subsequently, the decline continued, and by 2009 eelgrass was extirpated (Garbary et al. 2014). The benthos of the cove in 2018 comprised unvegetated (i.e. no macrophytes) sediment with a microalgal and bacterial biofilm, with snails (periwinkles and mud snails) and rare crabs (mudcrab and green crabs) being the conspicuous fauna.

The aim of this study was to determine whether BC has transitioned from a healthy eelgrass habitat to one in which the species can no longer survive. In other words, has the cove entered a new stable state devoid of eelgrass? We examined this question by transplanting eelgrass into BC from a nearby control site in Tracadie West Arm (TWA) with a healthy eelgrass bed, and carried out the equivalent transplantation within the bed at TWA. Our hypothesis was that BC had reached a state in which the habitat could not support the return of eelgrass based on transplantation of whole plants.

Findings from this study could help fill in the research gaps on eelgrass habitat recovery in eastern Canada. This is important because high density eelgrass beds in the Atlantic Coastal region of Nova Scotia are now considered as Ecologically and Biologically Significant Areas (EBSA; Hastings et al. 2014). 


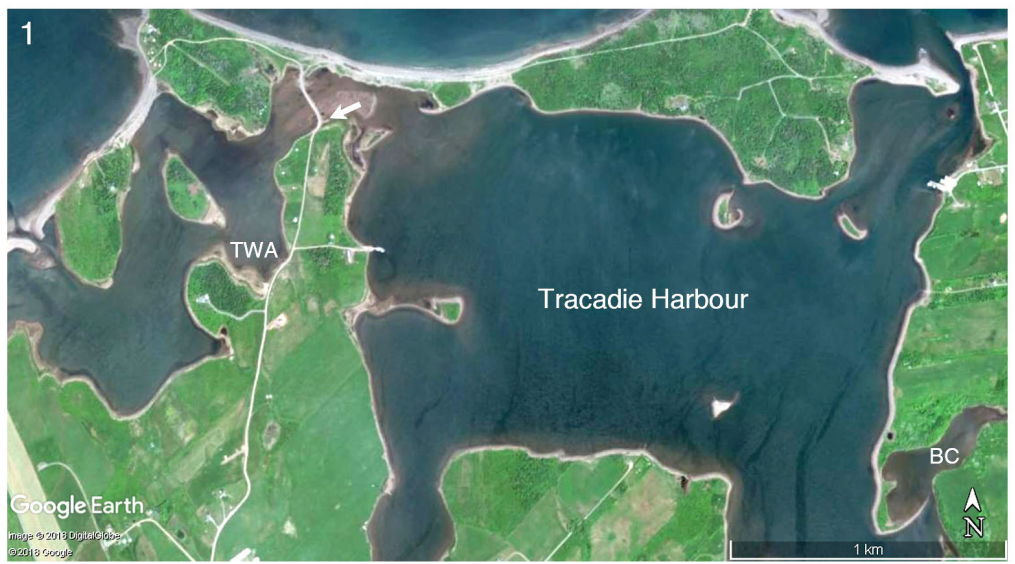

Fig 1 Map of study area showing locations of control site, Tracadie West Arm (TWA); and test site, Benoit Cove (BC), and site of culvert (arrow) joining Tracadie Harbour with TWA.

\section{STUDY SITES}

Benoit Cove (BC) in Tracadie Harbour (TH; $6.65 \mathrm{~km}^{2}$; Fig 1) was the experimental site. The donor control site, Tracadie West Arm (TWA), connects to the larger basin through a small culvert. The control site was in a small, sheltered area of TWA $\left(45^{\circ} 63.82^{\prime} \mathrm{N}\right.$; $\left.61^{\circ} 66.05^{\prime} \mathrm{W}\right)$. Beside the eelgrass bed is a salt marsh bed (ca. 25,000 $\mathrm{m}^{2}$ ) dominated by Spartina alterniflora. We selected TWA as the control site because it has an easily accessible, extensive eelgrass bed, that has been resilient following two decades of disturbance by green crabs and has seawater exchange with $\mathrm{TH}$.

$\mathrm{BC}\left(45^{\circ} 37.92^{\prime} \mathrm{N} ; 61^{\circ} 37.67^{\prime} \mathrm{W}\right)$ is a small, sheltered cove, which feeds into the larger basin of $\mathrm{TH}$ through a narrow passage with a sandbar that is exposed at low tide. A small freshwater stream runs into the head of the cove. $\mathrm{BC}$ has been devoid of eelgrass since at least 2009, and the benthos is comprised of soft sediment covered by fine flocculent material. On the south side of the cove, the intertidal zone has conspicuous populations of oysters (Crassostrea virginica) and scattered Fucus vesiculosus and Ulva intestinalis. On the north side, trees and shrubs shade a large portion of the cove. On the south side is a band ( $>5 \mathrm{~m}$ wide) of grass and shrub vegetation adjacent to a large hayfield. 


\section{FIELD METHODS AND OBSERVATIONS}

Eelgrass Transplant The transplant procedure was initiated during the first week of July 2018. The experimental design was similar to the 'Transplanting Eelgrass Remotely with Frames' method, or TERFS (Short et al. 2002). We used a modified frames technique described by Leschen et al. (2010) using PVC pipe (Fig 2). Each frame was $0.25 \times 0.25 \mathrm{~m}$ and constructed of PVC pipe $(1.5 \mathrm{~cm}$ internal diameter) and stiff plastic webbing (mesh size $3 \times 3 \mathrm{~cm}$ ). Every second column of the webbing was removed to prevent the mesh from blocking growth. Both sites had 12 frames with nine non-reproductive shoots per frame. As per Zhou et al. (2014), harvested eelgrass shoots had a rhizome length of $2-3 \mathrm{~cm}$ with roots. Collected shoots were stored in a cooler in seawater until attached to the frames.

Rhizome and leaf blade lengths were measured and the number of blades per shoot counted for each transplant. Shoot length was measured from the base of the sheath to the tip of the longest leaf blade. Rhizomes were fastened to the bottom of the webbing using $2.5 \mathrm{~mm}$ wide cable ties and were spaced $5 \mathrm{~cm}$ apart. This allowed us to plant the rhizome horizontally into the sediment at a depth of 1 to $2 \mathrm{~cm}$ (as per Short et al. 2002). A snorkeler secured the frames to the substratum using two $30-\mathrm{cm}$ tent pegs. Both TWA and BC had three subsites (A, B, and C) at which four frames were transplanted into each subsite. At BC, we systematically placed the frames in a square formation separated by $1 \mathrm{~m}$. Frame placement in TWA differed from $\mathrm{BC}$ because of the high density of eelgrass. Therefore, each frame was placed in a bare patch without eelgrass.
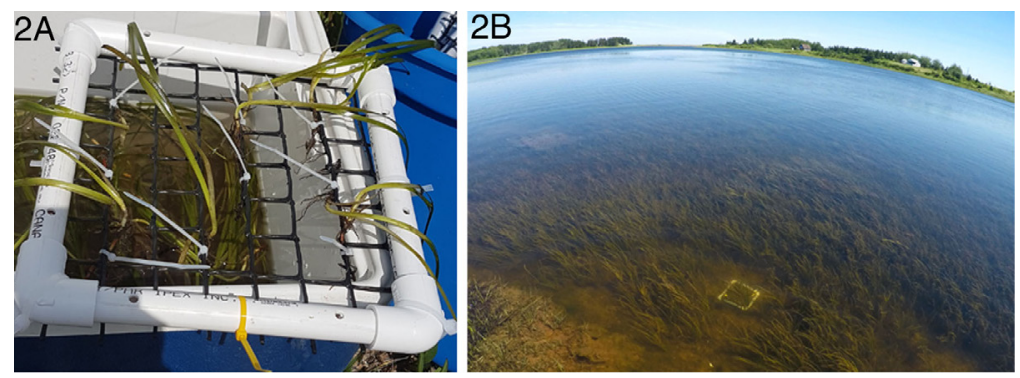

Fig 2 Eelgrass transplant procedure showing (A) a constructed PVC frame $\left(0.25 \mathrm{~m}^{2}\right)$ with nine eelgrass shoots attached and ready for transplant, and (B) in situ in Tracadie West Arm. 
We visited sites bi-weekly until the end of August. At each visit, we recorded the length of the longest blade per transplant and the number of dead missing shoots per frame. Transplants with only the rhizome portion remaining were considered dead. Eelgrass transplants that had slipped out of the cable ties were considered as missing and these plants were omitted from the initial population size. After 8 weeks, we removed the frames with the remaining eelgrass transplants attached. Final blade and rhizome lengths and the number of blades per shoot were recorded. Canopy height was calculated using the mean of the longest two-thirds of the plants present in each frame (similar to Hansen and Reidenbach 2013).

Abiotic Conditions Water temperature and salinity were recorded throughout the experiment. During each visit, nine water samples were collected: three near the surface, three at half depth, and three near the bottom at each subsite. Water temperature was measured using a glass alcohol thermometer to the nearest $0.5^{\circ} \mathrm{C}$. Salinity was measured to nearest $0.5 \%$ using a Portable Refractometer (Aqueous Lab, Las Vegas, Nevada, USA).

Sediment samples were collected using a 10 -cm-diameter homemade coring device to a depth of 10-15 cm. In BC and TWA, nine sediment samples were taken. We used 1-L Imhoff Settling Cones (Wheaton 06340-02, Vernon Hills, Illinois, USA) to estimate sediment composition. Sediment settling after $1 \mathrm{~min}$ (sand), $1 \mathrm{~h}$ (silt), and $1 \mathrm{~d}$ (clay) were recorded (Hossain et al. 2014).

\section{Green Crab Count}

In both BC and TWA, we estimated green crab abundance. Counting was done every two weeks by a snorkeler at each transplant site (ca. $8 \mathrm{~m}^{2}$ each). This was repeated at each biweekly visit.

\section{Species Richness}

Macrofauna and macroflora at BC and TWA were surveyed. A six-category abundance scale based on frequency was used: absent, low, low-moderate, moderate, moderate-high, or high. Changes in epiphyte cover were observed and noted throughout the study. Using snorkeling and underwater photos, we established a visual estimate of epiphytic and drift algal percent cover on the eelgrass blades and on the frames. Algal cover was considered in five categories: absent $(0 \%)$, low $(1 \%-25 \%)$, moderate $(25 \%-50 \%)$, high $(50 \%-75 \%)$, and intense $(75 \%-100 \%)$. 


\section{Data Analysis}

Using Minitab 18, transplant survival and canopy height from TWA and BC were compared using a nested ANOVA with Tukey's Honest Significant Difference Test (Tukey HSD test). The nested ANOVA was carried out because each measured parameter fell under multiple subgroups belonging to a specific group (Zar 2010). Other statistical tests were conducted using SPSS 25 and Microsoft Excel Data Analysis Package. Sediment composition was assessed using a Student's $t$-test.

\section{RESULTS}

\section{Eelgrass Transplant - Survival and Growth}

The transplant experiment occurred from 03 July to 29 August 2018. During the experiment, four shoots became reproductive, 22 individual shoots went missing and three frames were not found due to intense macroalgal cover or loss due to wave action. As a result, the initial eelgrass transplant populations for TWA and BC (108 each) were reduced to 72 and 91 transplants, respectively. Final survival and mean canopy height data for the missing frames were replaced using the mean imputation method in which the overall means from the other frames provided an estimate for the missing data (Zar 2010). This method was used only for the nested ANOVAs because of a requirement for equal sample sizes.

After the first 2 weeks, eelgrass transplant survival rate differed between TWA and BC (Fig 3). Tracadie Harbour had a final plant survivorship rate of $91.6 \%$ with six shoot mortalities. The three subsites ranged from $83.0 \% \pm 0.0 \%$ (subsite A) to $96.3 \% \pm 6.4 \%$ (subsite B). After 8 weeks, BC had a transplant survival of $15.4 \%$ and 77 shoot mortalities. Subsite survival ranged from $4.17 \% \pm 8.3 \%$ to $24.8 \% \pm$ $8.9 \%$. Transplant survival rates after 8 weeks significantly differed in TWA and $\mathrm{BC}(\mathrm{F}=122.025, \mathrm{P}<0.001)$. The Tukey HSD test revealed that there was no significant difference between subsites in TWA, but subsites A and B in BC were statistically different.

Rhizome length was recorded before and after transplantation. There were no significant changes in length at either site $(\mathrm{P}>0.9)$. In TWA, rhizome length was $7.1 \pm 4.4 \mathrm{~cm}$ and $7.2 \pm 4.4 \mathrm{~cm}$ at the start and end of the experiment, respectively. $\mathrm{BC}$ rhizome length was $7.1 \pm 3.4 \mathrm{~cm}$ and $7.0 \pm 3.8 \mathrm{~cm}$ at the start and end, respectively. 


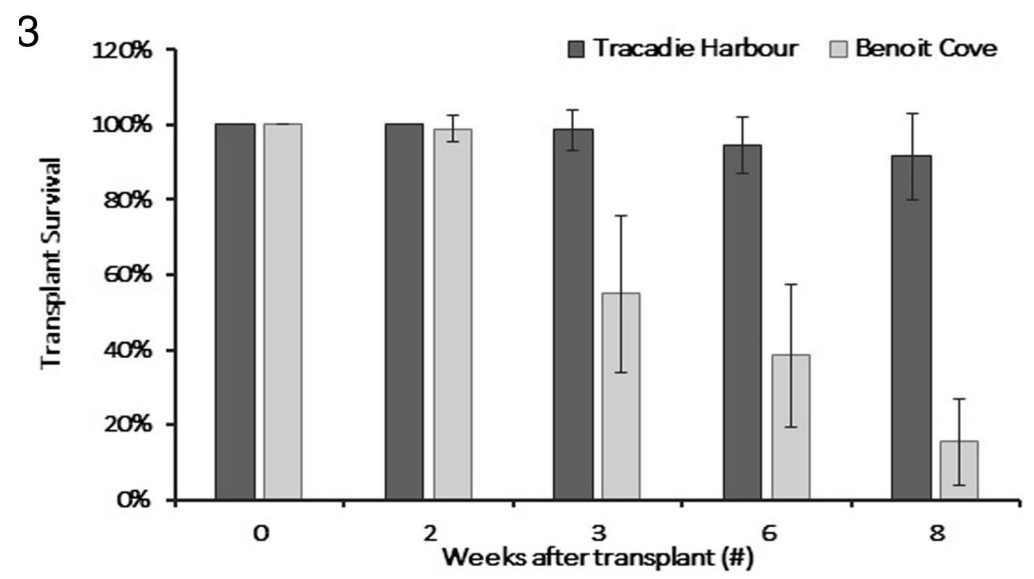

Fig 3 Transplant survival $( \pm$ s) over 8 weeks following transplantation into Tracadie West Arm and Benoit Cove.

For both sites, a declining trend occurred in all above-ground growth variables (Table 1). The initial five blades per shoot declined to 2.6 blades after 8 weeks (Student's $t$-test, $\mathrm{P}<0.001$ ). In addition, there was no significant difference in the number of blades per shoot between TWA and $\mathrm{BC}(\mathrm{P}=0.78)$.

Canopy height in BC declined faster than in TWA (Fig 4). In the first two weeks, both sites maintained a canopy height $>31 \mathrm{~cm}$. After 8 weeks, canopy height declined to $3.8 \pm 5.4 \mathrm{~cm}$ and $24.6 \pm 4.1 \mathrm{~cm}$ in $\mathrm{BC}$ and TWA, respectively $(\mathrm{P}<0.001)$.

\section{Temperature, Salinity and Sediment Composition}

TWA and $\mathrm{BC}$ had similar water temperature trends over the summer with means of $25.4 \pm 1.1^{\circ} \mathrm{C}$ and $24.9 \pm 1.1^{\circ} \mathrm{C}$ in TWA and $\mathrm{BC}$, respectively, with temperature extremes of $23^{\circ} \mathrm{C}$ to $27^{\circ} \mathrm{C}$. Salinity

Table 1 Summary of transplant above-ground growth characteristics. Values for blades per shoot, blade length $(\mathrm{cm})$, and canopy height $(\mathrm{cm})$ are means $\pm s$.

\begin{tabular}{lcccc}
\hline \multirow{2}{*}{ Plant Characteristics } & \multicolumn{2}{c}{ Tracadie West Arm } & \multicolumn{2}{c}{ Benoit Cove } \\
Initial & Final & Initial & Final \\
\hline Number of shoots & 72 & 66 & 91 & 14 \\
Number of blades & 388 & 173 & 579 & 38 \\
Blades per shoot & $5.0 \pm 1.2$ & $2.6 \pm 1.2$ & $5.4 \pm 1.6$ & $2.6 \pm 0.8$ \\
Blade length $(\mathrm{cm})$ & $27.5 \pm 8.1$ & $20.9 \pm 8.5$ & $29.8 \pm 8.3$ & $13.2 \pm 6.1$ \\
Canopy height $(\mathrm{cm})$ & $32.0 \pm 5.0$ & $24.5 \pm 4.1$ & $34.8 \pm 3.9$ & $3.8 \pm 5.4$ \\
\hline
\end{tabular}




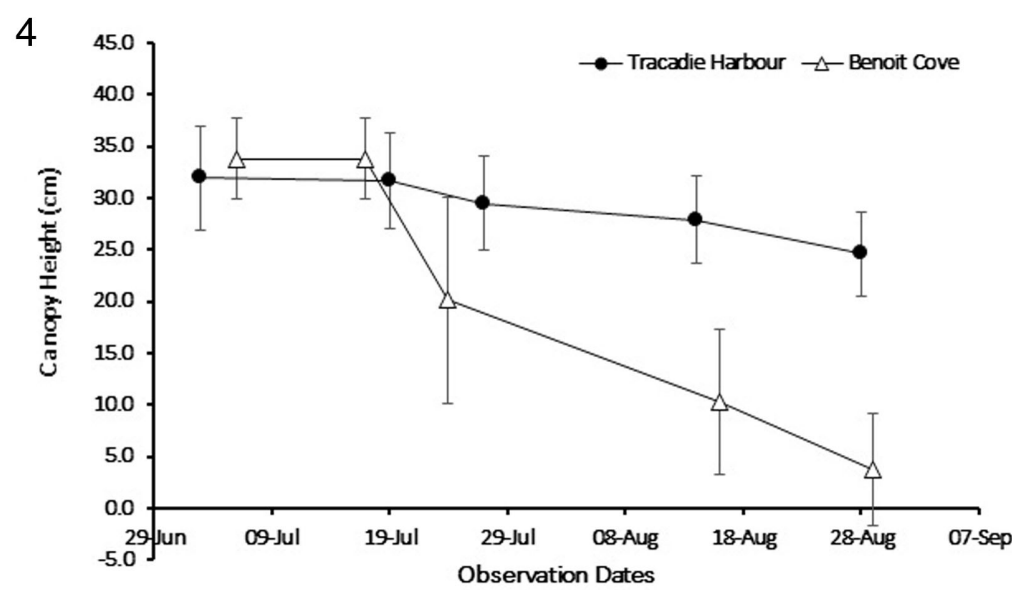

Fig 4 Canopy height $( \pm s)$ between July and August 2018 in Tracadie West Arm (TWA) and Benoit Cove (BC).

was also similar at $26.2 \pm 2.6 \%$ and $26.4 \pm 2.4 \%$ for BC and TWA, respectively.

Sediment in TWA and BC was composed mainly of silt and mud with extremely fine particulate matter (Table 2). Mean percent silt composition was $34.1 \% \pm 12.8 \%$ in TWA and $28.3 \% \pm 4.4 \%$ in $\mathrm{BC}$, which revealed that there was no significant difference between the two sites (Student's $t$-test, P $>0.15$ ). Similarly, there were no statistcal differences in clay composition $(\mathrm{P}=0.64)$. TWA had a mean sand composition of $0.80 \% \pm 0.00 \%$ which was significantly different than BC's mean sand composition of $2.08 \% \pm 0.01 \%(\mathrm{P}<0.001)$.

\section{European Green Crab Abundance}

Green crabs occurred at both sites but at different frequencies. Crab number per visit was significantly greater in TWA (24 and 62 per visit) than in $\mathrm{BC}$ ( 4 and 8 per visit, significant at $\mathrm{P}=0.0086$ ). In TWA, crabs also occurred near the transplant frames but did not

Table 2 Sediment composition at study sites in Benoit Cove and Tracadie West Arm; values are means $\pm s$.

\begin{tabular}{ccc}
\hline \multirow{2}{*}{ Sediment Component } & Tracadie West Arm & Benoit Cove \\
\hline Sand & $0.80 \% \pm 0.00 \%$ & $2.08 \% \pm 0.01 \%$ \\
Silt & $34.10 \% \pm 0.13 \%$ & $28.33 \% \pm 0.04 \%$ \\
Clay & $0.59 \% \pm 0.00 \%$ & $0.54 \% \pm 0.00 \%$ \\
\hline
\end{tabular}


seem to use the frames as often as the crabs in $\mathrm{BC}$ where most crabs were found beside or in the transplant frames along with several crab carapaces, legs, and empty shells. When macroalgal loading was high, crabs often hid under the algal mats covering the frames.

\section{Species Richness}

In addition to eelgrass, 40 species were observed that included algae, invertebrates and fish. TWA had $92.5 \%$ of these species and $\mathrm{BC}$ had $52.5 \%$. The most abundant animals in TWA were fish and grazers (Amphipoda, Tanaidacea, Isopoda). In BC, fish and grazers had low abundance or were absent. Of animal species in BC, 38.5\% were molluscs. The most abundant included the Eastern mudsnail (Tritia obsoleta), Common slipper limpet (Crepidula fornicata), and Eastern oyster (Crassostrea virginica). These species were either absent in TWA or in lower abundance than in BC.

At both sites, the dominant seaweed was the red alga Polysiphonia subtilissima. In BC, P. subtilissima was found attached to rocks at low water and as drift thalli on the transplant frames. These frames also had drift fronds of sea lettuce (Ulva lactuca). In TWA, large floating algal mats were often observed on the water surface and throughout the eelgrass bed. These mats were composed primarily of $P$. subtilissima and large fragments of other species including Ulva prolifera, Cladophora sp., and Chaetomorpha picquotiana. At both sites, algal loading increased during the experiment, but cover was greater in TWA. In TWA, $P$. subtilissima covered the eelgrass both as an epiphyte and as drift, whereas cover in BC was strictly as drift. After 8 weeks, the eelgrass in TWA had dense cover of both epiphytic and drift algae (75\%-100\%) and BC was moderately to highly covered $(50 \%-75 \%)$.

\section{DISCUSSION}

Eelgrass transplant results from this study are consistent with our initial hypothesis. As expected, the control site (TWA) outperformed the test site (BC) in terms of eelgrass survival (92\% vs $15 \%$, respectively). The two sites had the same salinity and temperature regimes and similar sediment with high silt ( $>28 \%$ ). With the complete absence of eelgrass in $\mathrm{BC}$, the biota was substantially different, with much lower species richness in $\mathrm{BC}$ (Appendix A). 
The presence and density of seagrass meadows can substantially influence the severity of sediment resuspension and turbidity (Hansen and Reidenbach 2013). Sediment resuspension and hydrodynamic conditions have caused local regime shifts in habitats that once supported a dense eelgrass bed, and complicate eelgrass recovery both naturally and through restoration efforts (Moksnes et al. 2018). This was confirmed during our field work in that BC had many days when turbidity precluded observation of transplants, whereas this did not occur in TWA. The transplants in TWA were surrounded by a dense eelgrass bed which limited sediment being raised into the water column. In BC, without vegetation to stabilize the sediment and reduce impact of wind and currents, sediment resuspension and turbidity were often high. We suggest that increased sediment resuspension and turbidity in $\mathrm{BC}$ impeded transplant survival by reducing light availability (indirect) and covering or burying the eelgrass blades (direct). We conclude that $\mathrm{BC}$ has entered a new stable state in which it is unlikely to return to its previous condition without large human intervention. In addition, there was an increase in epiphytic and drift algal cover which may have played a role. Eelgrass mortality and reduced growth are common responses to increased loading of algae because of decreased light available for photosynthesis (Vandermeulen 2005). TWA had a higher accumulation of epiphytic algae than $\mathrm{BC}$ and still maintained a significantly greater transplant survival. High eelgrass mortality in $\mathrm{BC}$ occurred because the site had too many environmental stressors which prevented transplants from establishing.

A limitation of this study was the season when eelgrass shoots were transplanted. Transplanting eelgrass during the summer is not recommended because there is a higher chance of large-scale mortality (CCE 2011). Additional physiological stress is put on plants during the summer because of increasing water temperature and decreasing light levels caused by epiphytic and drift algae (Park and Lee 2007, CCE 2011). Since eelgrass stops growing at water temperatures above $20^{\circ} \mathrm{C}$ and can lose shoot weight at $25-30^{\circ} \mathrm{C}$ (Touchette et al. 2003; Moreno-Marín et al. 2018), plant growth was not an accurate measurement of transplant success for this experiment. Therefore, conducting this study during fall or spring may have facilitated better establishment and growth. 
There was no evidence that green crabs impacted transplant survival at either site. Furthermore, BC had a mean green crab count of $0.01 \mathrm{crabs} \mathrm{m}^{-2}$, which was even lower than in TWA ( 0.08 crabs $\mathrm{m}^{-2}$ ). Without eelgrass, sufficient prey for the crabs is absent in BC. Following the disappearance of eelgrass in the 1930s, the Woods Hole area lost approximately one third of its species (Burkholder and Doheny 1968). In 2013, BC was depauperate in benthic invertebrates (Garbary et al. 2014).

Our sites may have had similar habitat characteristics prior to the green crab disturbance, but this is no longer the case. Eelgrass habitats, including TWA, have a higher abundance of species and are typically more diverse than unvegetated habitats like $\mathrm{BC}$ (McCullough et al. 2005). Following the assessment of biota in BC, species richness did not meet what would be expected for seagrass habitat in the region. Only a few invertebrates dominated the site, and these were not the species that are usually abundant in eelgrass beds.

We were unsuccessful at re-establishing eelgrass in BC. This cove seems to have entered a new stable state in which eelgrass is not colonizing naturally because of the recurring suspension of fine sediments and turbidity. These conditions also make eelgrass restoration difficult (Unsworth et al. 2015). Further work will be required to determine if restoration is possible with more substantial efforts. For instance, previous studies have found that transplant survival increases with an increase in planting unit size (Sheridan et al. 1998, van Keulen et al. 2003). Perhaps increasing the size and number of frames would allow denser patches of eelgrass transplants to become established, thus helping with sediment stabilization in areas like Benoit Cove. Regardless, the low density of green crabs in TWA is two orders of magnitude lower than crab numbers associated with eelgrass decimation (4.4 crabs $\mathrm{m}^{-2}$, Garbary et al. 2014). This suggests that they have reached an equilibrium with their environment and are not a current threat to eelgrass at this site.

Acknowledgements We thank Sydney Silver for assistance in both the laboratory and the field. This work was supported by NSERC grants to DJG. 


\section{REFERENCES}

Bertness, M.D. (2007). Atlantic shorelines: natural history and ecology. Princeton University Press, Princeton, New Jersey, USA.

Burkholder, P.R., \& Doheny, T.E. (1968). The biology of eelgrass. Lamont Geological Observatory of Columbia University 1227: 1-120.

Cornell Cooperative Extension Program (CCE). (2010). Methods of restoring eelgrass. Long Island's Seagrass Conservation. www.seagrassli. org/restoration/methods.html (accessed Feb. 4, 2018).

Davis, R.C., \& Short, F.T. (1997). Restoring eelgrass, Zostera marina L., habitat using a new transplanting technique: the horizontal rhizome method. Aquatic Botany 59: 1-15.

Duarte, C.M., Marbà, N., \& Santos, R. (2004). What may cause loss of seagrasses? In: Borum, J., Duarte, C.M., Krause-Jensen, D., \& Greve, T.M. (eds.), European seagrasses: An introduction to monitoring and management. The EU Project Monitoring and Managing of European Seagrasses (M\&MS). pp. 24-32.

Garbary, D.J., Miller, A.G., Williams, J., \& Seymour, N.R. (2014). Drastic decline of an extensive eelgrass bed in Nova Scotia due to the activity of the invasive green crab (Carcinus maenas). Marine Biology 161: $3-15$.

Green, E.P., \& Short, F.T. (2003). World atlas of seagrasses. University of California Press, Berkeley, California, USA.

Hansen, J.C.R., \& Reidenbach, M.A. (2013). Seasonal growth and senescence of a Zostera marina seagrass meadow alters wave-dominated flow and sediment suspension within a coastal bay. Estuaries and Coasts 36: 1099-1114.

Hanson, A.R. (2004). Status and conservation of eelgrass (Zostera marina) in Eastern Canada. Environment Canada, Canadian Wildlife Service, Atlantic Region Technical Report Series 412: viii. + 40 pp.

Hastings, K., King, M., \& Allard, K. (2014). Ecologically and biologically significant areas in the Atlantic coastal region of Nova Scotia. Canadian Technical Report of Fisheries and Aquatic Science 3107: xii + 174 p.

Hossain, M.B., Marshall, D.J., \& Venkatramanan, S. (2014). Sediment granulometry and organic matter content in the intertidal zone of the Sungai Brunei estuarine system, northwest coast of Borneo. Carpathian Journal of Earth and Environmental Sciences 9: 231-239.

Leschen, A.S., Ford, K.H., \& Evans, N.T. (2010). Successful eelgrass (Zostera marina) restoration in a formerly eutrophic estuary (Boston Harbor) supports the use of a multifaceted watershed approach to mitigating eelgrass loss. Estuaries and Coasts 33: 1340-1354.

Malyshev, A., \& Quijón, P.A. (2011). Disruption of essential habitat by a coastal invader: new evidence of the effects of green crabs on eelgrass beds. ICES Journal of Marine Science 68: 1852-1856. 
Matheson, K., McKenzie, C.H., Gregory, R.S., Robichaud, D.A., Bradbury, I.R., Snelgrove, P.V.R., \& Rose, G.A. (2016). Linking eelgrass decline and impacts on associated fish communities to European green crab Carcinus maenas invasion. Marine Ecology Progress Series 548: 31-45.

McCullough, D.M., Doherty, P.A., Schaefer, H.L., Deacoff, C., Johnston, S.K., Duggan, D.R., Petrie, B.D., \& Soukhovtsev, V.V. (2005). Significant habitats: Atlantic Coast Initiative (SHACI), Halifax Regional Municipality - Units 4-6. Canadian Manuscript Report of Fisheries and Aquatic Science 2724: xvii + 501 pp.

Moksnes, P.-O., Eriander, L., Infantes, E., \& Holmer, M. (2018). Local regime shifts prevent natural recovery and restoration of lost eelgrass beds along the Swedish west coast. Estuaries and Coasts 41: 1712-1731.

Moreno-Marín, F., Brun, F.G., \& Pedersen, M.F. (2018). Additive response to multiple environmental stressors in the seagrass Zostera marina L. Limnology and Oceanography 63: 1528-1544.

Muehlstein, L.K., Porter, D., \& Short, F.T. (1991). Labyrinthula zostera sp. nov., the causative agent of wasting disease of eelgrass, Zostera marina. Mycologia 93: 180-191.

Neckles, H.A. (2015). Loss of eelgrass in Casco Bay, Maine, linked to green crab disturbance. Northeastern Naturalist 22: 478-500.

Orth, R.J., \& McGlathery, K.J. (2012). Eelgrass recovery in the coastal bays of the Virginia Coast Reserve, USA. Marine Ecology Progress Series 448: 173-176.

Park, J.-I., \& Lee, K.-S. (2007). Site-specific success of three transplanting methods and the effect of planting time on the establishment of Zostera marina transplants. Marine Pollution Bulletin 54: 1238-1248.

Seymour, N.R., Miller, A.G., \& Garbary, D.J. (2002). Decline of Canada geese (Branta canadensis) and common goldeneye (Bucephala clangula) associated with a collapse of eelgrass (Zostera marina) in a Nova Scotia estuary. Helgoland Marine Research 56: 198-202.

Sheridan, P., McMahan, G., Hammerstrom, K., \& Pulich Jr., W. (1998). Factors affecting restoration of Halodule wrightii to Galveston Bay, Texas. Society for Ecological Restoration 6: 144-158.

Short, F.T., \& Burdick, D.M. (1996). Quantifying eelgrass habitat loss in relation to housing development and nitrogen loading in Waquoit Bay, Massachusetts. Estuaries 19: 730-739.

Short, F.T., Kopp, B.S., Gaeckle, J., \& Tamaki, H. (2002). Seagrass ecology and estuarine mitigation: a low-cost method for eelgrass restoration. Fisheries Science 68: 1759-1762.

Short, F.T., \& Short, C.A. (2003). The seagrasses of the western North Atlantic. In: Green, E.P., \& Short, F.T. (eds.), World atlas of seagrasses. University of California Press, Los Angeles, CA, USA. pp. 207-215.

Touchette, B.W., Burkholder, J.M., \& Glasgow, H.B. (2003). Variations in eelgrass (Zostera marina L.) morphology and internal nutrient composition as influenced by increased temperature and water column nitrate. Estuaries 26: 142-155. 
Unsworth, R.K.F., Collier, C.J., Waycott, M., Mckenzie, L.J., \& CullenUnsworth, L.C. (2015). A framework for the resilience of seagrass ecosystems. Marine Pollution Bulletin 100: 34-46.

Vandermeulen, H. (2005). Assessing marine habitat sensitivity: a case study with eelgrass (Zostera marina L.) and kelps (Laminaria, Macrocystis). DFO Canadian Science Advisory Secretariat Research Document 2005/032: ii +53 p.

Vandermeulen, H., Surette, J., \& Skinner, M. (2012). Responses of eelgrass (Zostera marina L.) to stress. DFO Canadian Science Advisory Secretariat Research Document 2011/095: vi + 43 p.

Van keulen, M., Paling, E.I., \& Walker, C.J. (2003). Effect of planting unit size and sediment stabilization on seagrass transplants in western Australia. Restoration Ecology 11: 50-55.

Waycott, M., Duarte, C.M., Carruthers, T.J., Orth, R.J., Dennison, W.C., Olyarnik, S., Calladine, A., Fourqurean, J.W., Heck, K.L., Hughes, A.R., Kendrick G.A., Kenworthy, W.J., Short, F.T., \& Williams, S.L. (2009). Accelerating loss of seagrasses across the globe threatens coastal ecosystems. Proceedings of the National Academy of Sciences of the United States of America 106: 12377-12381.

Wilson, E. (2019). Absence of recovery in a degraded eelgrass (Zostera marina L.) bed in Nova Scotia, Canada: results from a transplant study. Master's Dissertation. University of Akureyri, Iceland. http://hdl.handle. net/1946/34034.

Zar, J.H. (2010). Biostatistical analysis. 5th ed. Pearson, Upper Saddle River, New Jersey, USA.

Zhou, Y., Liu, P., Liu, B., Liu, X., Zhang, X., Wang, F., \& Yang, H. (2014). Restoring eelgrass (Zostera marina L.) habitats using a simple and effective transplanting technique. PLoS One 9: e92982. 


\section{APPENDICES: SPECIES ABUNDANCE}

Table A.1 Abundance of species in Tracadie West Arm from 3 July to 28 August, 2018.

\begin{tabular}{lc}
\hline Taxon & Abundance Level \\
\hline Marine Algae & \\
Ulva lactuca (Sea lettuce) & Low \\
Ulva intestinalis (Gutweed) & Moderate \\
Ulva prolifera & Moderate-high \\
Cladophora sp. & High \\
Chaetomorpha picquotiana & High \\
Ulothrix flacca & Moderate \\
Gomontia polyrhiza & Low-moderate \\
Gracilaria sp. & Low-moderate \\
Polysiphonia subtilissima & High \\
Ceramium diaphanum & Moderate-high \\
Pylaiella littoralis (Angel hair) & Low \\
Fucus vesiculosus (Bladder wrack) & Low \\
\hline
\end{tabular}

\section{Invertebrates}

Carcinus maenas (European green crab)

Rhithropanopeus harrisii (Harris mud crab)

Pagurus sp. (Hermit crab)

Crangon septemspinosa (Sand shrimp)

Palaemonetes vulgaris (Grass shrimp)

Idotea balthica (Baltic isopod)

Littorina littorea (Periwinkle snail)

Tritia obsoleta (Eastern mudsnail)

Crassostrea virginica (Eastern oyster)

Mercenaria mercenaria (Northern quahog)

Mytilus edulis (Blue mussel)

Hediste diversicolor (Ragworm)

Capitella sp. (Polychaete)

High

Low-moderate

Low

Moderate

Low-moderate

Moderate-high

Low

Low

Moderate

Low-moderate

Low

Low-moderate

Moderate

\section{Chordates}

Anguilla rostrata (American eel)

Low

Gasterosteus aculeatus (Three-spined stickleback)

High

Fundulus heteroclitus (Mummichog)

High

Fundulus diaphanous (Killifish)

High

Menidia menidia (Atlantic silverside)

High 
Table A.2 Abundance of species in Benoit Cove, from 6 July to 29 August, 2018.

\begin{tabular}{lc}
\hline Taxon Abundance Level & \\
\hline Marine Algae & Moderate-high \\
Ulva lactuca (Sea lettuce) & Low-moderate \\
Ulva intestinalis (Gutweed) & Moderate \\
Ulva prolifera & Low-moderate \\
Cladophora sp. & High \\
Polysiphonia subtilissima & Low \\
Stylonema alsidii & Moderate \\
Fucus vesiculosus (Bladder wrack) & Low \\
Chorda filum (Sea lace) & \\
\hline Invertebrates & Moderate \\
Carcinus maenas (European green crab) & Moderate \\
Rhithropanopeus harrisii (Harris mud crab) & Low \\
Crangon septemspinosa (Sand shrimp) & Low-moderate \\
Littorina littorea (Periwinkle snail) & High \\
Tritia obsoleta (Eastern mudsnail) & High \\
Crassostrea virginica (Eastern oyster) & High \\
Crepidula fornicata (Common slipper limpet) & Low \\
Mercenaria mercenaria (Northern quahog) & Moderate-high \\
Hediste diversicolor (Ragworm) & Moderate-high \\
Capitella sp. (Polychaete) & \\
Chordates & Low \\
Gasterosteus aculeatus (Three-spined stickleback) &
\end{tabular}

Table A.3 Abundance of species from the orders Amphipoda and Tanaidacea, in Benoit Cove and Tracadie West Arm; A, absent.

\begin{tabular}{lcc}
\hline Species & Tracadie West Arm & Benoit Cove \\
\hline Amphipoda & & \\
Corophium volutator & High & A \\
Corophium sp. & High & Low \\
Gammarus mucronatus & Moderate & A \\
Gammarus finmarchicus & Low & A \\
Gammarus sp. & High & Low \\
\hline
\end{tabular}

\section{Tanaidacea}

Chondrochelia sp.

Moderate

A

Leptochelia sp.

Low-moderate

A 
